\title{
Influence of land cover and structure of tree stands on pollen deposition in Zaborski Landscape Park
}

\author{
Anna Filbrandt-Czaja, Milosz Deptuła, Andrzej Nienartowicz \\ Nicolaus Copernicus University, Faculty of Biology and Environmental Protection, \\ Laboratory of Ecological Modelling, \\ 87-100 Toruń, ul. Lwowska 1, Poland \\ e-mail: afczaja@umk.pl
}

\begin{abstract}
The paper presents a comparison of modern pollen deposition in Tauber traps after one-year exposure at two research sites - Laska and Widno, located in the northern part of the Zaborski Landscape Park in the Pomerania Province (Northern Poland). The studied sites were circular in shape with a radius of $2 \mathrm{~km}$ and an area of 1256 ha each. They were characterised by similar contribution of forest and non-forest areas, as well as similar species composition and area covered by tree species. Both sites differed, however, in the location of traps in relation to forest areas and distribution of deciduous trees amid pine monocultures. At the former site, a Tauber trap was placed in the open field, i.e. in xerothermic meadow, in the western part of the Laska village. At the latter site, a trap was placed on the borderline between meadows of the Widno village and the surrounding forests. At the site of Laska, scattered deciduous trees occurred mostly in the form of small clusters amid extensive pine monocultures surrounding the village. Whereas at the site of Widno, deciduous tree species covered larger areas in the form of more fertile oak-hornbeam forests, beech forests and birch woods amid pine forests. The size of area covered by tree species and the amount of pollen deposition by these trees were positively correlated at both sites. In addition, the average annual pollen deposition was calculated for each site for seven most abundant tree species during the period of 1999-2010. By comparing the arithmetic means, it was found that the pollen deposition at the site of Widno is higher for most of the studied arboreal species compared with the site of Laska, but these differences are statistically significant only in the case of birch and hornbeam.

Surface pollen samples from the sites of Laska and Widno were compared in terms of pollen deposition with 4 other sites from the Zaborski Landscape Park and with the site located in the Las Piwnicki nature reserve in the Torun Basin.
\end{abstract}

Key words: palynology, modern pollen deposition, relevant source area of pollen, landscape structure, Tuchola Forest Biosphere Reserve.

\section{Introduction}

Two aspects prevail in the research on modern pollen deposition, i.e. determination of the relationships between the vegetation structure and the size and composition of the pollen spectrum, and changes in the deposition of pollen grains occurring under the impact of climatic factors. The former aspect of research applies to samples from the same climate zone or even from one physical-geographical region, but collected in different plant communities or different landscape types. The latter case usually involves sam- ples from different, often geographically distant regions, although collected within the same vegetation formation or a similar syntaxonomic unit of a higher rank, with at least some common components of the vegetation cover. When research is conducted in terms of climate impact, also samples from the same region can be analysed, or even from the same sites, but they have to be collected in the subsequent growing seasons possibly over a long period of time.

The research on modern pollen deposition, undertaken by palynologists and ecologists from the Nicolaus Copernicus University, are performed in terms of both as- 
pects and with both sample collection methods applied. The research on relationships between the phytocoenosis structure and the modern pollen deposition was carried out by Filbrandt-Czaja (2005), Filbrandt-Czaja et al. (2003), Hrynowiecka et. al. (2007) and Nienartowicz et al. (2011) in Tuchola Forest and in the Torun Basin located in northern and central Poland, respectively. The fraction of Taxus baccata pollen in pollen spectra from forest with varying contribution of this species in the tree stand was analysed by Noryśkiewicz $(1997,2006)$. The research was conducted in Tuchola Forest, in the Leon Wyczółkowski „Cisy Staropolskie" Nature Reserve. Although this forest complex had been legally protected since 1957 , protection measures were applied by Prussian foresters to the yew tree stand already in 1828. The effect of climate differences on $\mathrm{Fa}$ gus sylvatica pollen production was studied and assessed by Filbrandt-Czaja et al. (2003) within the framework of the Pollen Monitoring Programme in cooperation with palynologists from several European countries. Their joint work (Pidek et al. 2010) presents differences in the pollen deposition of this species based on the analysis of samples from Tauber traps placed along the N-S gradient in eastern and central Europe.

As evidenced by our research on the relationships between the phytocoenosis structure and the modern pollen deposition, pollen from a further distance had a major contribution in palynological samples. Therefore, in our study, the vegetation structure was assessed over a larger area around a sample collection site. To enable the comparison of our results with the research of other authors from Poland and other European countries, we did not analyse the deposition on moss branches, but the deposition from standard pollen traps.

Our study aims at comparing the annual pollen deposition with the actual vegetation over a considerable area of the Tuchola Forest. We assume that results obtained in the present study will contribute to more precise interpretation of pollen diagrams and will enable to answer the question whether land cover and structure of tree stands is reflected in the pollen deposition.

\section{Study area}

The research was conducted in Tuchola Forest in Northern Poland. According to regional classification of natural and forest aspects of Poland (Trampler et al. 1990), this region curves over a distance of ca. $60 \mathrm{~km}$ from the town of Nowe on the Vistula River in the east, to the town of Szczecinek in the west. Based on this approach, the region covers ca. $5.000 \mathrm{~km}^{2}$ area with one of the largest forest complexes in Poland. Pine monocultures dominate, which were introduced more than two hundred years ago to replace the cut down deciduous forests. More fertile habitats and forest stands rich in deciduous species were preserved mostly in the eastern part of the forest complex. Other important ecosystems in the region, in terms of nature and economy, include lakes and rivers, e.g. the Brda and Wda Rivers together with channels built in the $19^{\text {th }}$ century in their drainage basins.

Whereas according to physical and geographical division of Poland proposed by Kondracki (2000), Tuchola Forest is situated within the more eastern part of the area recognised by foresters. Boundaries of the region presented by different authors were compiled by Kowalewski (2002). The author also presented his own concept of Tuchola Forest boundaries based on the range of geological strata with varying water permeability. The region boundaries presented by this author are very similar to those of the „Tuchola Forest” Biosphere Reserve, the largest biosphere reserve in Poland - over $3.200 \mathrm{~km}^{2}$, and designated within the framework of the UNESCO MAB Programme on 2 June 2010. The Biosphere Reserve is situated on the borderline between the Pomeranian province and the $\mathrm{Ku}-$ jawy-Pomerania province. As much as $73.8 \%$ of the biosphere reserve area overlaps with the Natura 2000 area (code PLB220009), called Tuchola Forest and nominated based on the EU Birds Directive.

There are four landscape parks within this large area, which constitute buffer zones of the Biosphere Reserve. In one of them, i.e. in Zaborski Landscape Park (Fig. 1), 6 sites were selected to study the modern pollen deposition. The sites were located in the villages of Laska and Widno, situated in the northern part of the landscape park, to the north of Tuchola Forest („Bory Tucholskie”) National Park, which is the largest of the 26 core areas of the polycentric Biosphere Reserve. Both villages, Laska and Widno, are also included within other protection forms Natura 2000 area PLB220001, called, ,Wielki Sandr Brdy (Great Sandur of the Brda River)", designated based on the EU Birds Directive, and Natura 2000 area PLH220026, called Sandr Brdy (Sandur of the Brda River) and designated based on the EU Habitat Directive.

In terms of administrative divisions, both villages are included in the village council of Rolbik and the commune of Brusy, which are included in the district of Chojnice. Both villages are situated within the Forest Division of Przymuszewo, included in the Regional Directorate of State Forests in Torun.

The village of Laska is situated in the valley of the Zbrzyca River at its estuary into Lake Laska, which is a nature reserve included in the core area of the Biosphere Reserve together with 25 other nature reserves of Tuchola Forest. The village of Widno is also located in the Zbrzyca valley near the place where the river flows from Lake Milachowo. Both villages were created in the $17^{\text {th }}$ century as so-called forest wilderness areas. After the Prussian forest divisions of Laska and Zwanshof were established in the 


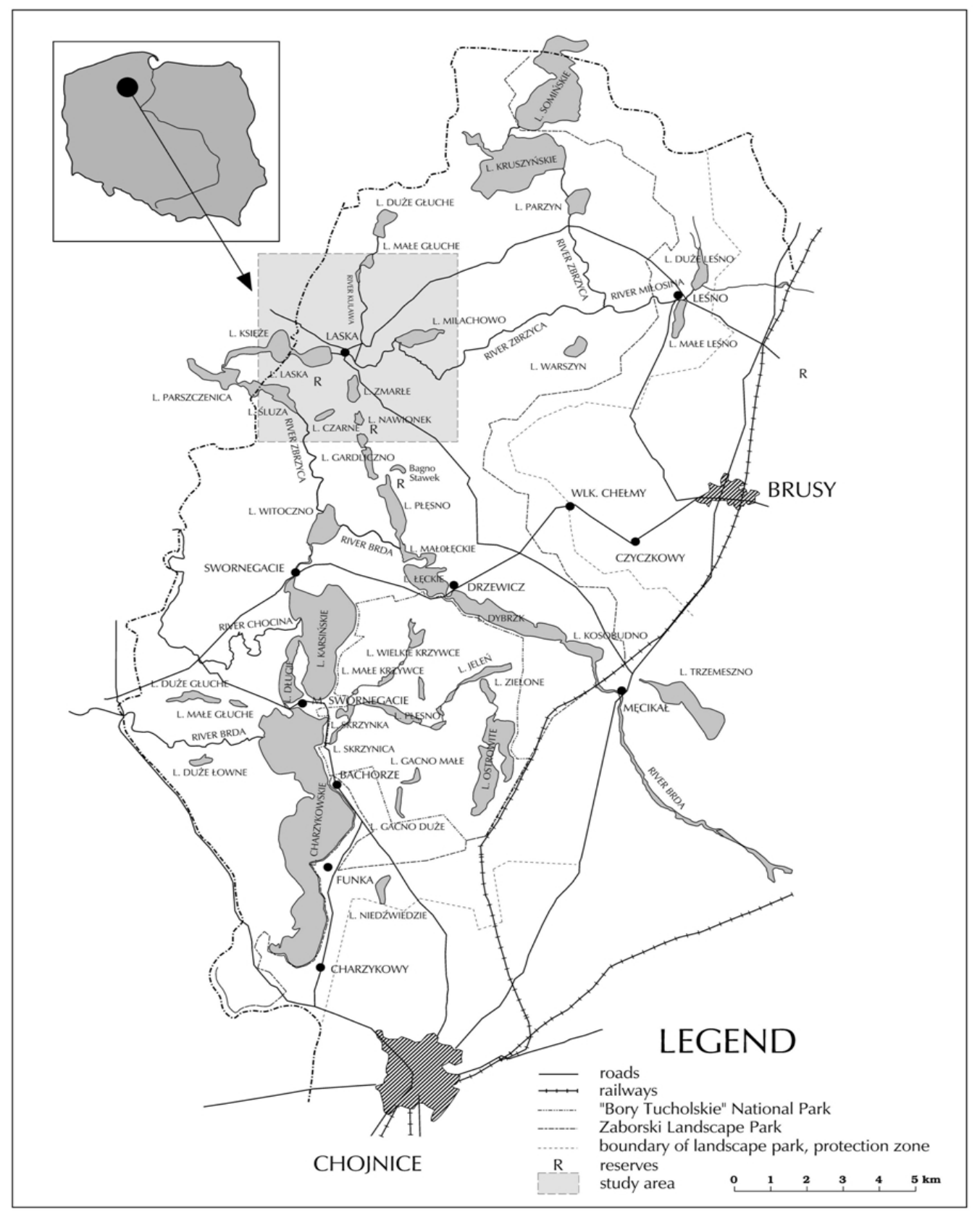

Figure 1. Location of the study area in Zaborski Landscape Park

$19^{\text {th }}$ century, and after 1920 - the Polish forest divisions of Laska and Przymuszewo, both villages were inhabited by forest workers. During the last twenty years, as a consequence of the Przymuszewo Forest Division restructuring, and the fact that the land and buildings were purchased by employees from the State Forests, both villages have become summer holiday villages.

Six pollen traps were installed in both villages in autumn 1998, within meadows adjacent to village buildings. At the Laska site, it was a mesophilic meadow with some admixture of xerothermic species, located within the NCU
Research Station. In Widno it was a wet meadow situated between buildings in the village centre and Lake Milachowo. Two containers were placed on the borderline between the villages and the surrounding forests. In the northern part of the Laska village where traps were installed, fresh pine forest occurred with some admixture of deciduous trees - silver birch, small-leaved lime, beech and oak growing in small clusters. In the north-eastern end of Widno, the pollen trap was placed in the vicinity of the hornbeam-oak forest with some admixture of Scots pine, eastern white pine and silver birch, which covers the 
slopes of the Milachowo lake channel. This was the only fragment of the mixed lime-oak-hornbeam forest preserved in the northern part of the Zaborski Landscape Park, with a monospecific, more than 100-year-old stand of Fagus sylvatica adjacent from the inner side of the forest complex. Most likely the beech was introduced here in the $19^{\text {th }}$ century in the habitat of oak-hornbeam forest, although Sokołowski (1965) classified the forest communities occurring in this area as the association of Luzulo pilosaeFagetum. At the periphery of the village, to the west of oak-hornbeam forest and beech forest, there is a forest area planted with silver birch.

The next Tauber traps were placed in forests surrounding the villages. One trap was placed near the village of Laska, in more than 100-year old pine forest in the habitat of fresh pine forest, on the right side of the road running from Laska to Zapceń. The forest research site near Widno was located in the aforementioned oak-hornbeam forest to the north-east of the village. Other sides of the Widno village, like in the village of Laska, are surrounded by fresh pine forests, only in some places turning into dry or more fertile pine forests indicating a higher contribution of deciduous species in the previous generations of trees.

Except for the above-mentioned forest types, also alder forests occur in Laska and Widno. They grow along the Zbrzyca River and its tributary - Kulawy, around big lakes Laska and Milachowo, and around smaller ones Sieczonek and Żabionek. The black alder is accompanied by willows. The largest concentration of this species, i.e. a plantation planted by Prussian foresters in the early $20^{\text {th }}$ century, is located near the place where the Zbrzyca River flows from Lake Milachowo. A small area with Tilia cordata is located south-west of Widno. The linden was planted here by Prussian foresters to increase the species diversity of tree stands dominated by Scots pine. Two small areas of beech forest are found in the valley of Kulawy near Laska. In recent years, beech trees play an increasingly important role in fresh pine forests surrounding the two villages. Whereas in the pine forest between Lake Sieczonek and Widno, the contribution of hornbeam increases in the understory and undergrowth. This reflects the regeneration of former deciduous forests.

Monumental Norway spruce and pedunculate oak trees grow in both villages in small parks created next to administration buildings of the Przymuszewo Forest Division. Monumental oak trees occur also near Lake Sieczonek, at the edge of small plots, which until recently were cultivated by villagers of Laska. In orchards of both villages there are fruit trees, mostly apple and pear trees, but also some cherry and plum trees.

\section{Methods}

\subsection{Analysis of palynological samples}

Pollen deposition has been monitored by standard one-year round pollen traps constructed according to Tauber's description (Tauber 1974; Hicks \& Hyvärinen 1986; Hicks et al. 1996). Standard Tauber traps with $5 \mathrm{~cm}$ diameter of opening were used. The trap bottom was covered by a mixture of glycerine, thymol and formalin in the recommended proportions. Traps stayed in the ground all year round (October-October) and their contents were subjected to laboratory treatment. The first step in the laboratory treatment consists in sieving through a coarse sieve and adding 5 Lycopodium tablets followed by filtering and Erdtman's acetolysis by standard methods used in pollen analysis (Faegri \& Iversen 1989; Berglund \& Ralska-Jasiewiczowa 1986). The final stage of the laboratory treatment is colouring of pollen grains followed by microscopic analysis during which a minimum of 1000 pollen grains of trees and shrubs (AP) and dwarf-shrubs and herbs (NAP) is counted.

Samples at the six sites were defined as: 1 - Laska Open, 2 - Laska Edge, 3 - Laska Forest, 4 - Widno Open, 5 - Widno Edge, 6 - Widno Forest. Their distribution in the study area is presented in Figure 2. The observations were conducted from 1999. Till 2011 the complete annual data were obtained only for the site of Laska Open; for other five sites the obtained results were incomplete. No data available for certain years resulted from the fact that traps were destroyed by animals or stolen by people who penetrate forests in search of blueberries and mushrooms.

The following was determined: pollen deposition of individual taxa (the amount of grains $\mathrm{cm}^{-2}$ year ${ }^{-1}$ ), the percentage of pollen of individual types of trees, the contribution of pollen of deciduous (AP/BL) and coniferous trees (AP/NL), and the contribution of AP (arboreal pollen) and NAP (pollen of herbal plants) in the deposition. The results of calculations for consecutive years at the sites of Laska Open and Widno Edge, as well as mean values for several years from six sites (i.e. all the surveyed years, for which calculations were possible) were included in the tables. The Microsoft Excel spreadsheet was used for calculations and drawing graphs.

\subsection{Landscape structure analysis and statistical as- sessment of relationships between the vegetation cover and modern pollen deposition}

Geographic coordinates were determined for all the sites using a GPS receiver. Points were plotted on the topographic map of the area and on the overlapping economic forest map. Spatial analyses were performed with the software ArcView 3.1. A circular buffer zone with a radius of $2 \mathrm{~km}$ was drawn around the sites (the area of 1256 ha 


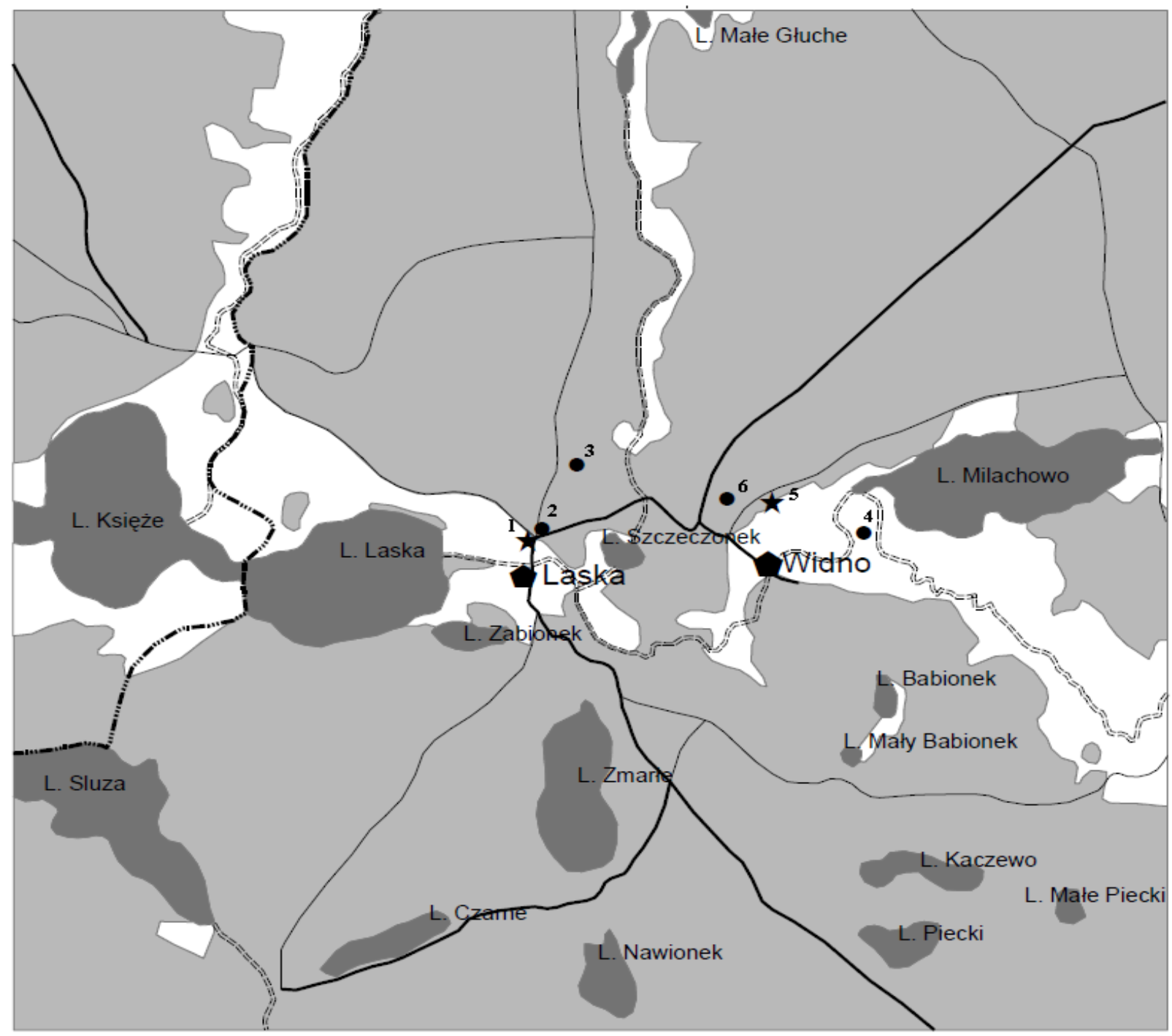

$0 \quad 250500 \quad 1000 \mathrm{~m}$

\section{Legend:}

$\star \quad$ main pollen traps $\bullet \quad$ other pollen traps

villages $\square$ deforested area

forested area

lakes

boundary of Zaborski Landscape Park

major roads

$==$ rivers

Figure 2. Distribution of the research sites and pollen traps near Laska and Widno

$=12.56 \mathrm{~km}^{2}$ ). The radius length of the analysed circles results from the assumption that it represents a relevant source area of pollen (RSAP) coming from local vegetation. The land use structure was read from maps and a list of forest subdivisions located within buffer zones was compiled. A forest survey of the Przymuszewo forest district provided information about land use at each sampling site, habitat quality, vegetation cover, age and species composition of the main and secondary forest canopy. The land cover structure around each pollen trap was calculated and pie charts were drawn with the software Excel.
Spearman's correlation coefficient was calculated with the software Past for samples from Laska Meadow and Widno Edge between the landscape acreage of individual tree species and the average deposition of their pollen (pollen accumulation rate PAR) recorded in samples of annual deposition during 12 years. The area covered by individual trees within a radius of $2 \mathrm{~km}$ from a Tauber trap was included in the calculations. The software Excel and Student's test were used to calculate the significance of the difference in the pollen deposition for individual species of trees between the sites of Laska Open and Widno Edge. 


\section{Results}

4.1. Correlation between the arboreal pollen deposition and the area covered by individual species

\section{Laska Open}

The site Laska Open is largely afforested. The contribution of forests within a radius of $2 \mathrm{~km}$ comes to $81.3 \%$, although the Tauber trap collecting the annual pollen deposition is located in the open field, in the territory of the Laska forest village.

Pine covers the largest area at the analysed site, followed by birch and alder (Table 1), while spruce is of lesser significance. Oak and hornbeam have the smallest contribution in the composition of forest plant communities (Fig. 3A).

Trees covering the largest areas around the trap, i.e. pine, birch and alder, have the highest averaged values of pollen deposition. Whereas trees of lesser significance in the landscape are characterised by small values of pollen deposition. Spruce diverges from this pattern - within a radius of $2 \mathrm{~km}$ from the trap, it covers an area of $8.54 \mathrm{ha}$, and its pollen deposition is very low. Picea abies produce three

A.

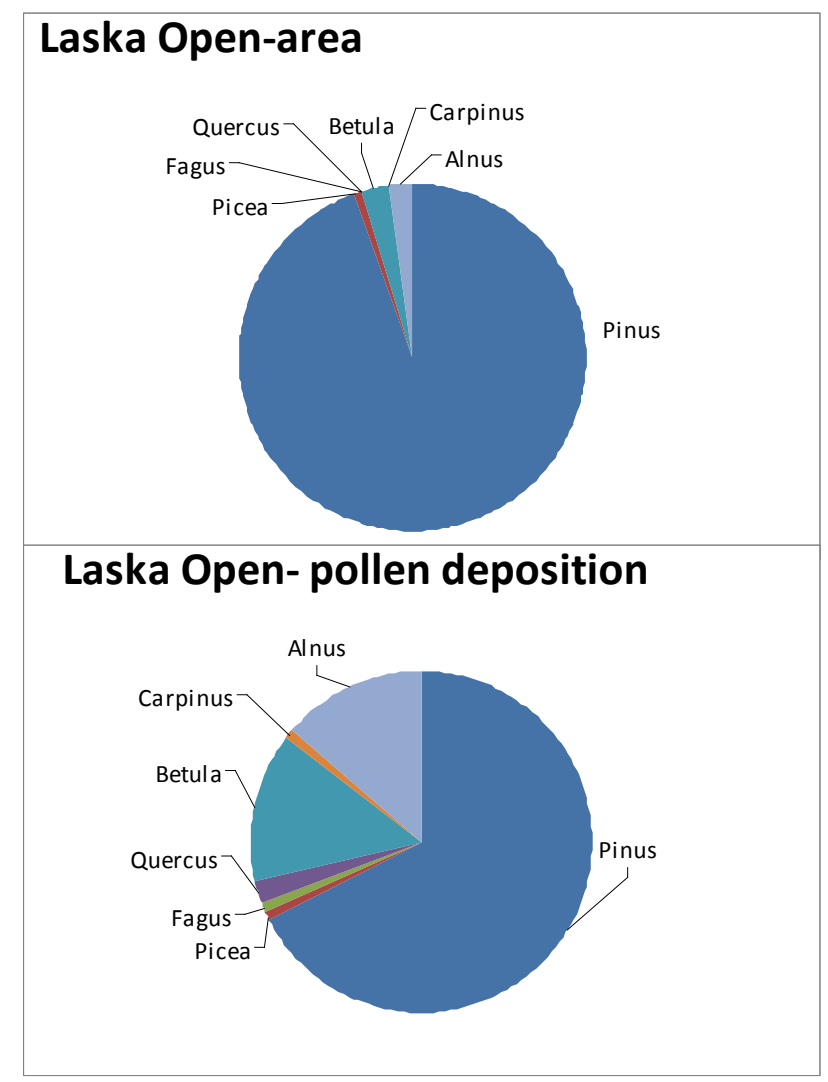

Table 1. Contribution of individual arboreal species in the cover of a circle with a radius of $2 \mathrm{~km}$ (area $1256 \mathrm{ha}$ ) and in the pollen deposition at the two main sites: Laska Open and Widno Edge

\begin{tabular}{|l|c|c|c|c|}
\hline Stand & \multicolumn{2}{|l|}{ Laska Open } & \multicolumn{2}{l|}{ Widno Edge } \\
\hline Taxa of tree & $\begin{array}{l}\text { area within } \\
\text { circle with } \\
\text { a radius of } 2 \\
\text { km [ha] }\end{array}$ & $\begin{array}{l}\text { average } \\
\text { PAR }\end{array}$ & $\begin{array}{l}\text { area within } \\
\text { circle with } \\
\text { a radius of } \\
\text { km } \\
\text { [ha] }\end{array}$ & $\begin{array}{l}\text { average } \\
\text { PAR }\end{array}$ \\
\hline Pinus sylvestris & $1,021.13$ & 9,719 & $1,033.69$ & 19,047 \\
\hline Picea abies & 8.54 & 125 & 7.54 & 246 \\
\hline Betula & 26.88 & 2,044 & 29.89 & 11,141 \\
\hline Alnus & 22.73 & 1,962 & 18.71 & 5,369 \\
\hline Fagus sylvatica & 2.01 & 128 & 2.01 & 127 \\
\hline Quercus & 0.5 & 329 & 0.5 & 707 \\
\hline $\begin{array}{l}\text { Carpinus } \\
\text { betulus }\end{array}$ & 0.25 & 104 & 0.25 & 1,089 \\
\hline Total & $1,086.44$ & 15,098 & $1,096.49$ & 41,721 \\
\hline
\end{tabular}

B.

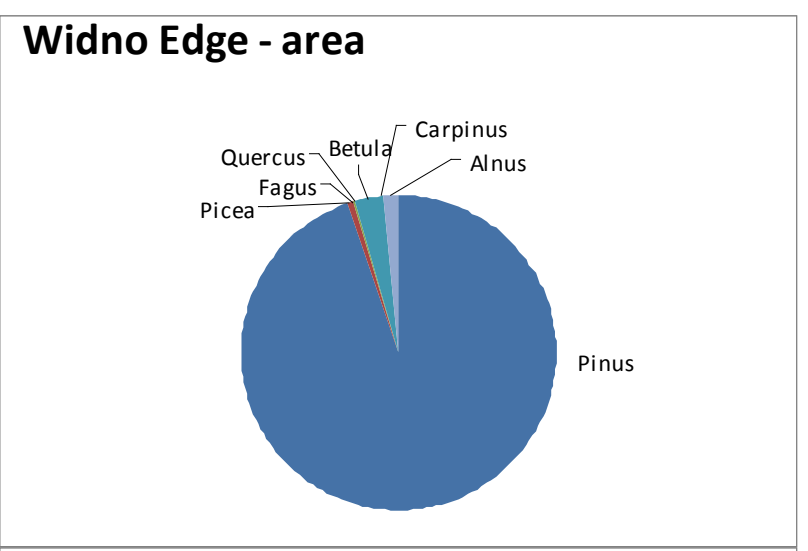

\section{Widno Edge- pollen deposition}

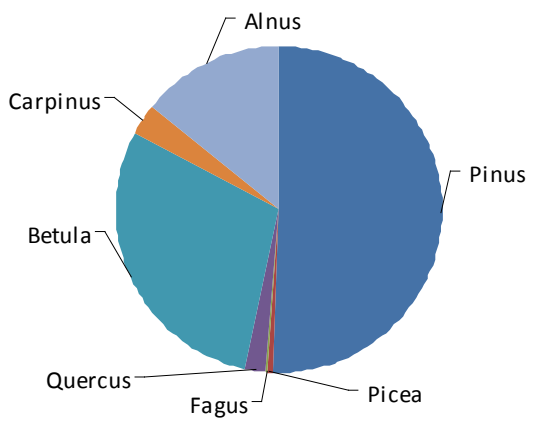

Figure 3. Contribution of individual arboreal species in the cover of a circle with a radius of $2 \mathrm{~km}$ and in the pollen deposition at the two main sites: A - Laska Open, B - Widno Edge 
times less pollen than pine and its pollen grains due to their dimensions and weight are not able to spread over large distances (Obidowicz et al. 2004). Despite this exception, the amount of arboreal pollen deposition is determined by the area covered by trees, which is confirmed by the value of Spearman's correlation coefficient $r_{s}$, i.e. 0.90476. This correlation is statistically significant $(\mathrm{p}=0.00339)$.

\section{Widno Edge}

At this site, the Tauber container collecting the annual pollen deposition is placed on the forest edge. The extent of land afforestation within a radius of $2 \mathrm{~km}$ from the pollen trap is similar to that observed at the site of Laska Open. Also in this area pine covers the largest acreage, and is followed by birch and alder (Table 1), and then by spruce (Fig. 3B). In terms of area covered by particular trees, both sites are similar to each other. Pine had the highest values of pollen deposition, and was followed by birch and alder, and then by hornbeam; Carpinus betulus covers the smallest area at the analysed site, i.e. only 0.25 ha. When analysing the deposition values at Widno Edge, one can observe much higher influx values referring to pollen deposition per $1 \mathrm{~cm}^{2}$ per year as compared to Laska Open. Only beech pollen deposition remains at the same level compared to Laska. In this case, the area covered by individual trees is correlated with the deposition of their pollen grains $\left(\mathrm{r}_{\mathrm{s}}=\right.$ 0.78571, $\mathrm{p}=0.027927$ ).

When comparing both analysed sites, one can conclude that they are very similar in terms of afforestation, as well as in the area covered by individual species of trees. There are, however, differences in the size of pollen deposition. This applies to total arboreal pollen deposition and pollen deposition of pine, birch, alder, hornbeam and oak trees. As evidenced by the $t$ test, in most cases these differences are not statistically significant $(<0.05)$. Only hornbeam and birch pollen deposition are statistically significantly different at both studied sites $(\mathrm{t}=0.042$ and $\mathrm{t}=0.007)$.

\subsection{Contribution of deciduous and coniferous pollen}

The ratio of deciduous and coniferous pollen was calculated based on the average deposition of their pollen grains at the sites of annual deposition monitoring. Seven sites were included in the comparison. Six of them are located in Tuchola Forest, and one in the „Las Piwnicki” nature reserve. The latter site was included in the comparison as a reference site, as it is the only site located outside the Tuchola Forest in the deciduous forest with a small admixture of pine. Annual pollen deposition in „Las Piwnicki” is characterised by the highest contribution of deciduous tree pollen at the analysed sites. Minor dominance of deciduous tree pollen was recorded at the sites of Widno, where Tauber trap were placed in the forest and on the forest edge,

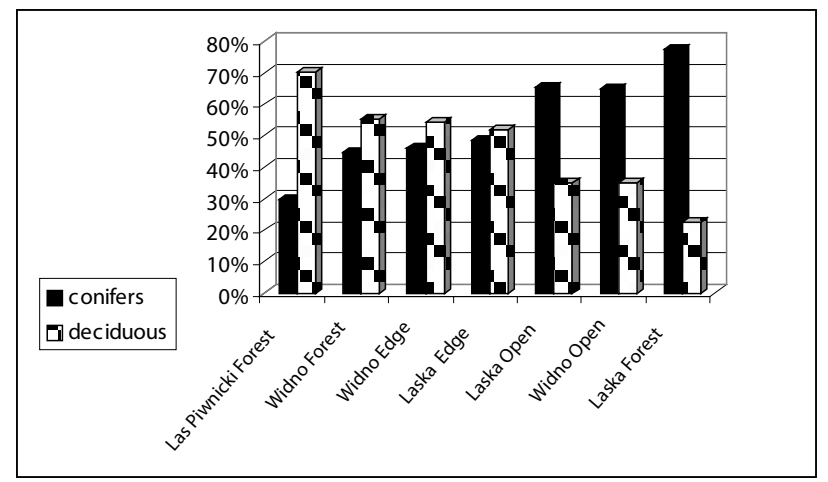

Figure 4. Comparison of coniferous and deciduous pollen percentage contribution at particular sites

as well as in Laska - on the forest edge (Fig. 4). At these sites, deciduous trees grow in the close proximity of a trap, which undoubtedly has a major effect on the amount of pollen deposition. The three other sites are characterised by significant dominance of coniferous tree pollen in the samples of annual deposition. Those are sites in the Laska and Widno meadows and in the Laska pine forest. As evidenced by the results, the number of deciduous tree pollen in palynological samples is affected by a distance between these trees and a pollen trap.

\section{Discussion and conclusions}

The presented results of the research on the annual pollen deposition include only values for arboreal pollen deposition. The use of pollen traps enables the calculation of pollen accumulation rate (PAR; not just pollen percentage), which provides a more objective basis for interpreting the local vegetation. The efficiently spreading pine and birch pollen is the dominant component of the spectra at the studied sites of Laska Open and Widno Edge. These trees cover the largest areas within a radius of $2 \mathrm{~km}$ from a Tauber trap. In the case of the analysed sites located in the largely afforested area where pine is the most important component of forest plant communities, high contribution of Pinus pollen results from the dominance of this component both in the local and regional pollen rain (Prentice et al. 1987; Jackson \& Kearsley 1998). The size of the analysed sites results from the assumption that it represents a relevant source area of pollen (RSAP) coming from local vegetation. The size of the source area was defined based on the literature data, as there are many papers dealing with the determination of pollen source area (Calcote 1995; Broström et al. 2002; Sugita et al. 1999; Nielsen 2003; Veski et al. 2005). Sugita (1994) defines RSAP as a distance beyond which there is no correlation between the pollen deposited at a given site and the surrounding vegetation. 
Although according to Calcote (1995), there is a nonlinear relationship between the presence of pine and birch in the vegetation cover and their representation in pollen spectra, and therefore pollen percentage values for these taxa cannot be related to the size of area covered by their communities, the results presented above contradict Calcote's thesis. Statistically significant negative correlations were found between the size of area covered by particular trees and pollen deposition at the two analysed sites with the longest series of observations (Laska Open, Widno Edge). These results confirm that pollen deposition is determined by landscape and vegetation types (Hicks 1988; Broström et al. 1998; Bunting 2002). The area covered by individual species of trees was similar in size at both analysed sites, but arboreal pollen deposition at Widno Edge was higher compared to Laska Open. The differences were, however, not statistically significant, except for hornbeam and birch. Both sites differ also in the location of a Tauber container. In Laska, the pollen trap is located in the open field with no trees within several dozen metres, and in Widno - on the forest edge within the immediate vicinity of trees. This certainly affects the size of pollen deposition, particularly in the case of oak and hornbeam. Carpinus betulus is basically poorly represented in palynological samples, because pollen grains of this species are mostly transported within ca. $1 \mathrm{~km}$ (Jackson 1990; Sugita 1998).

This property of deciduous pollen determines the proportions between the pollen of deciduous and coniferous trees in palynological samples. This is also associated with the landscape context in which a container collecting the pollen rain was placed. If a pollen monitoring site was located in the open field, then the pollen of coniferous trees predominated in the palynological spectrum over pollen of deciduous trees, as pine pollen is privileged in such a situation. It is produced in very large quantities and is capable of spreading over considerable distances, which results in influx of Pinus sylvestris pollen grains onto deforested areas.

As evidenced by the conducted research, the total arboreal pollen deposition was higher at the site of Widno (total PAR 41,721 grains $\mathrm{cm}^{-2}$ year $^{-1}$ ), and the deciduous tree pollen predominated compared to the site of Laska Open (total PAR 15,098 grains $\mathrm{cm}^{-2}$ year-1), although the contribution of trees at both circular sites was similar. Perhaps the differences result from the presence of more fertile types of forest, i.e. mixed lime-oak-hornbeam forest, beech forest and birch woods at the site of Widno Edge. At the site of Laska Open, trees dominating in such types of forest occur as scattered single specimens, as an admixture in pine monocultures, or at most - in the form of small clusters, and they do not form different deciduous forest communities. Perhaps blooming and pollen production by deciduous trees, growing on habitats of coniferous forest is smaller than on more fertile habitats of deciduous forests preserved amid coniferous forests.
We conclude that the amount of pollen deposition by individual species of trees at the analysed sites of Laska Open and Widno Edge is determined by the contribution of these species in tree stands. One can also say that the percentage content of deciduous pollen is affected by a higher contribution of forest habitats in the landscape and by a distance between a pollen trap and forest stands occurring on these habitats.

\section{References}

Berglund B. E. \& Ralska-Jasiewiczowa M., 1986, Pollen analysis and pollen diagrams, [in:] B. E. Berglund (ed.) Handbook of Holocene Palaeoecology and Palaeohydrology, John Willey \& Sons, Chichester: 455-484.

Broström A., Gaillard M.-J., Ihse M. \& Odgaard B., 1998, Pollen-landscape relationships in modern analogues of ancient cultural landscapes in southern Sweden a first step towards quantifications of vegetation openness in the past, Vegetation History and Archaeobotany 7: 189-201.

Broström A., Sugita S., Gaillard M.-J. \& Pilesjö P., 2002, Estimating spatial scale of pollen dispersal in the cultural landscape of southern Sweden, [in:] A. Broström (ed.), Estimating source area of pollen and pollen productivity in the cultural landscape of southern Sweden - developing a palynological tool for quantifying past plant cover, LUNDQUA Thesis, Lund University, Lund: 101-115.

Bunting M. J., 2002, Detecting woodland remnants in cultural landscapes: modern pollen deposition around small woodlands in northwest Scotland, Holocene 12 (3): 291-301.

Calcote R., 1995, Pollen source area and pollen productivity: evidence from forest hollows, Journal of Ecology 83: 591-602.

Faegri K. \& Iversen J., 1989, Podręcznik analizy pyłkowej [Pollen analysis handbook], Wydawnictwo Geologiczne, Warszawa.

Filbrandt-Czaja A., 2005, The influence of temperature and rainfall on pollen production in Bory Tucholskie (the North-West Poland), $5^{\text {th }}$ International Meeting of Pollen Monitoring Programme in Varna, Volume of Abstracts.

Filbrandt-Czaja A., Noryśkiewicz A. M., Noryśkiewicz B. \& Pidek I., 2003, Variation of tree pollen influx values in several forested regions of Poland, [in:] XVI INQUA Congress, Programs with Abstracts, Desert Research Institute, Reno, CO.

Hicks S., 1988, The representation of different farming practices in pollen diagrams from northern Finland, [in:] H. H. Birks, H. J. B. Birks, P. E. Kaland, D. Moe (eds.) The cultural landscape past, present and future, Cambridge University Press, Cambridge: 189-207. 
Hicks S., Ammann B., Latałowa M., Pardoe H. \& Tinsley H., 1996, European Pollen Monitoring Programme: Project description and Guidelines, Oulu University Press, Oulu.

Hicks S. \& Hyvärinen V.-P., 1986, Sampling modern pollen deposition by means of Tauber traps: some considerations, Pollen et Spores 28: 219-242.

Hrynowiecka-Czmielewska A., Filbrandt-Czaja A. \& Nienartowicz A., 2007, Modern pollen -vegetation relationships in the Tuchola Forest, Ecological Questions 8: $47-70$.

Jackson S. T., 1990, Pollen source area and representation in small lakes of the Northeastern United States, Review Palaeobotany and Palynology 63: 53-76.

Jackson S. T. \& Kearsley J. B., 1998, Quantative representation of local forest composition in forest-floor pollen assemblages, Journal of Ecology 86: 474-490.

Kondracki J., 2000, Geografia regionalna Polski [Regional geography of Poland], Wydawnictwo Naukowe PWN, Warszawa.

Kowalewski G., 2002, Granice Borów Tucholskich [Borders of Tuchola Pinewoods], [in:] J. Banaszak, K. Tobolski (eds.), Park Narodowy „Bory Tucholskie” na tle projektowanego rezerwatu biosfery [Tuchola Forest National Park against a background of the planned biosphere reserve], Park Narodowy „Bory Tucholskie”, Charzykowy: 121-138.

Nielsen A. B., 2003, Pollen based quantitative estimation of land cover: Relationships between pollen sedimentation in lakes and land cover as seen on historical maps in Denmark AD 1800, Institute of Geography, Faculty of Science, University of Copenhagen, Ph.D. Thesis, Copenhagen.

Nienartowicz A., Filbrandt-Czaja A., Piernik A., Jabłoński P., Kunz M. \& Deptuła M., 2011, Modern pollen rain in heathlands and adjacent forest phytocoenoses in Northern and Central Poland, Ecological Questions 15: 127-151.

Noryśkiewicz A. M., 1997, Analiza palinologiczna ściółki leśnej rezerwatu „Cisy Staropolskie” im. Leona Wyczółkowskiego we Wierzchlesie, [Palynological analysis of forest litter of the Leon Wyczółkowski Nature Reserve „The Old Polish Yews” in Wierzchlas], [in:] E. Krasicka-Korczyńska (ed.) Ochrona gatunkowa na obszarach chronionych [Species protection on protected areas], Towarzystwo Miłośników Borów Tucholskich, Tuchola: 55-61.

Noryśkiewicz A. M., 2006, Historia cisa w okolicy Wierzchlasu w świetle analizy pyłkowej [The history of yew in the region of Wierzchlas in the light of pollen analysis], Wydawnictwo UMK, Toruń.
Obidowicz A., Ralska-Jasiewiczowa M., Kupryjanowicz M., Szczepanek K., Latałowa M. \& Nalepka D., 2004. Picea abies (L.) H. Karst., [in:] M. Ralska-Jasiewiczowa, M. Latałowa, K.Wasylikowa, E. Madeyska, H. E., JR.Wright, C. Turner (eds.). Late Glacial and Holocene history of vegetation based on isopollen maps. Isopollen history of trees and shrubs. W. Szafer Institute of Botany, Polish Academy of Sciences, Kraków: $147-159$.

Pidek I. A., Svitavská-Svobodova H., van der Knaap W. O., Noryśkiewicz A. M., Filbrandt-Czaja A., Noryśkiewicz B., Latałowa M., Zimny M., Święta-Musznicka J., Bozilova E., Tonkov S., Filipova-Marianova M., Poska A., Giesecke T. \& Gikov A., 2010, Variation in annual pollen accumulation rates of Fagus along a N-S transect in Europe based on pollen traps, Veg. History Archaeobot. 19: 259-270.

Prentice I. C., Berglund B. E. \& Olsson T., 1987, Quantitative forest composition sensing characteristics of pollen samples from Swedish lakes, Boreas 16: 43-54.

Sokołowski A. W., 1965, Zespoły leśne Nadleśnictwa Laska w Borach Tucholskich [Forest associations of the Laska Forestry District in Bory Tucholskie (Tuchola Forest)], Fragm. Flor. Geobot. 11: 96-119.

Sugita S., 1994, Pollen representation of vegetation in quaternary sediments: theory and method in patchy vegetation, Journal of Ecology 82: 881-897.

Sugita S., 1998, Modelling pollen representation of vegetation, Palaeoclimate Research 27: 1-16.

Sugita S., Gaillard M. J. \& Broström A., 1999, Landscape openness and pollen records: a simulation approach, The Holocene 9: 409-421.

Tauber H., 1974, A static non-overload pollen collector, New Phytol. 73: 359-369.

Trampler T., Kliczkowska A., Dmyterko E., Sierpińska A. \& Matuszkiewicz W., 1990, Regionalizacja przyrodniczo-leśna na podstawach ekologiczno-fizjograficznych [Nature and forest regionalization on the ecological and physiographic basis], Państwowe Wydawnictwo Rolnicze i Leśne, Warszawa.

Veski S., Koppel K. \& Poska A., 2005, Integrated palaeoecological and historical data in the service of fine-resolution land use and ecological change assessment during the last 1000 years in Rõuge, southern Estonia, Journal of Biogeography 32: 1473-1488. 
